\title{
Innovation and Entrepreneurship Education Reform of Business Administration Major: A Chinese Case Study
}

\author{
Yuran Jin*, Xinrui Zhang \\ School of Business Administration, University of Science and Technology Liaoning, Anshan, China \\ Email address: \\ jinyuran@163.com (Yuran Jin)
}

\section{To cite this article:}

Yuran Jin, Xinrui Zhang. Innovation and Entrepreneurship Education Reform of Business Administration Major: A Chinese Case Study. Education Journal. Vol. 5, No. 2, 2016, pp. 27-32. doi: 10.11648/j.edu.20160502.12

Received: April 28, 2016; Accepted: May 7, 2016; Published: May 14, 2016

\begin{abstract}
It is suitable, urgent and realistic for business administration major to carry on the innovation and entrepreneurship education reform. The business administration major of University of Science and Technology Liaoning has earlier begun to integrate the innovation and entrepreneurship education into the major education in China. It has gotten a series of reform achievements so as to be a representative case for this study. The case study method is used to track the whole reform process, collect the reform details, and summarize the typical successful experience. The case study shows the reform covers 4 aspects: training program, curriculum system, teaching resources and teacher team, including 23 measures, such as the updated training program, new training concept and teaching mode, new practice system, creating entrepreneurial platform and club, new course framework and course system, implementation of credits alternative plan, using $U$ type classroom, developing new teaching resources and practice bases, cultivating a number of expert teachers, setting up an omnibus teaching staff and so on. The research result embodies the emphasis and trends of innovation and entrepreneurship education reform in the business administration major. The related majors can get beneficial reference from this research.
\end{abstract}

Keywords: Innovation and Entrepreneurship, Education Reform, Business Administration Major,

University of Science and Technology Liaoning

\section{Introduction}

In recent years, China's economy has achieved rapid growth, which provides an unprecedented opportunity for college students to start a business. In this background, a lot of majors from universities in China have tried to carry out innovation and entrepreneurship education reform [1, 2]. Business administration major is an important branch of management disciplines, which cultivates senior applied talents generally with professional knowledge and ability of economy, law and enterprise management. It is just suitable, urgent and realistic to carry on the innovation and entrepreneurship education reform $[3,4]$. The reasons are as follows. Firstly, the business administration major is suit be reformed. The knowledge structure of business administration discipline has inherent advantages in terms of innovation and entrepreneurship for college student. The students of this major can learn the human resource management, financial management, logistics management, production management, marketing, enterprise strategy management and so on about the enterprise operation. The reform in business administration major can effectively boost the students to start a business, enhance the innovation ability of students. Secondly, it is urgent for business administration major. In today's fierce competition in the business community, the traditional training ideas and methods of business administration major have been unable to meet the social real needs $[5,6,7]$, it is very urgent for business administration major to adjust its major cultivation program. What's more, both the development of national economy and the career planning of college students have the realistic need for innovation and entrepreneurship education. In view of the current severe employment situation in China, the government has introduced a number of policies to support innovation and entrepreneurship development of college students [8, 9]. More and more students of business administration major desire to accept entrepreneurial skills training and exercise the business combat skills as early as possible during the period of school $[3,8,10]$.

Innovation and entrepreneurship education in colleges 
have matured in some developed countries, which have achieved good educational achievements [11, 12]. In particular, the history of innovation and entrepreneurship education in the United States has been more than 50 years. The university carrying on innovation and entrepreneurship education earliest was Harvard University in 1947[13]. Stanford University started the innovation and entrepreneurship education in 1949 [14]. Entrepreneurship course in Babson College started in 1967 [15], which designed a set of famous entrepreneurship practice teaching outlines for undergraduate students. According to the different needs and abilities to learn knowledge of undergraduate students, it designed a set of courses to meet the students' cognition, as shown in Table 1 [16]. In developing countries, China is paying more and more attention to the innovation and entrepreneurship education. A lot of scholars have carried out the relevant research [8, 9, 17]. For example, Wu [17] expounded the necessity to build a new system of entrepreneurship education in colleges and universities to, after the analysis of the related concepts of innovation and entrepreneurship education. Shen [18] believes that teaching oriented colleges and universities are supposed to reflect the target orientation of service area, service form, and cultivation type. Wang [19] analyzed the core content of innovation and entrepreneurship education, combed the problems of innovation and entrepreneurship education, and conducted a discussion on how to promote innovation and entrepreneurship education. Guo, Sun and Han [20] put forward the countermeasures for innovation and entrepreneurship education reform of ordinary colleges and universities, based on the analysis of the differences between the key universities and the ordinary universities. On the basis of the above research, some scholars have begun to research the innovation and entrepreneurship education reform of business administration major. Among them, some scholars carried out the comprehensive study. For example, Zhu and $\mathrm{Wu}$ [21] demonstrated the necessity of carrying out patent-related education in business administration major, pointing out it is a powerful starting point to promote the innovation and entrepreneurship education in colleges and universities in China. Chen [22] analyzed the problems existing in the training of professional talents from the perspective of innovation and entrepreneurship, and conducted an in-depth discussion from the aspect of training objectives, curriculum provision, and teaching mode and so on. Yi [10] has put forward a new course system for business administration major (innovation and entrepreneurship direction) in the open universities through the research on their talent training goal and talent training standard. In addition, there are also some scholars to carry out case studies, For example, Deng [23] explored the mode and experience of innovation and entrepreneurship education reform in colleges and universities, taking the innovation and entrepreneurship class of business administration major in Beijing City University for the specific research object. Li, Li and Yin [24] took the business administration major of Changzhou College as an example to analyze the innovation and entrepreneurship education system from the aspects of theoretical teaching and practical teaching.

Table 1. Innovation and Entrepreneurship Courses for Undergraduate in Babson College.

\begin{tabular}{llll}
\hline The First year & The Second year & The Third year & The Fourth year \\
\hline $\begin{array}{l}\text { Innovation and } \\
\text { entrepreneurship courses }\end{array}$ & The courses & Create entrepreneurship、Business finance, & $\begin{array}{l}\text { Corporate Entrepreneurship, Case study of } \\
\text { entrepreneurial combat, Entrepreneur }\end{array}$ \\
for freshmen & accelerating & Business plan, Family management mechanism, & \begin{tabular}{l} 
marketing, Strategy and structure \\
\hline
\end{tabular}
\end{tabular}

\section{Methodology}

\subsection{Research Design}

The case study method can provide the systematic views for researchers to establish a more in-depth and comprehensive understanding of some phenomena and theories through the direct investigation and thinking as far as possible [25]. Many problems in the field of education can be resolved by the case study method [26, 27, 28]. In this paper, the case study method is used to track the whole reform process of the case, collect the reform details of the case, and summarize the typical successful experience.

\subsection{Selected Case}

The business management major of University of Science and Technology Liaoning was founded in 1985. After many years of development, it has been the first-grade discipline master degree program of Business Administration. Based on the natural advantages of the knowledge structure of business administration major, it has earlier explored to integrate innovation and entrepreneurship education into the training of professional talents. Nowadays, on the basis of major regular class, it has set up an entrepreneurship practice class. The major regular class emphasizes the improvement of innovation spirit and professional ability. The entrepreneurship practice class emphasizes the cultivation of entrepreneurial awareness, entrepreneurial ability, and entrepreneurial spirit. Taken together, the business management major of University of Science and Technology Liaoning has earlier carried out the innovation and entrepreneurship education reform, and has achieved fruitful results. Therefore, it owns a good research representative. Taking it as the case study object, it not only can reflect the research frontier, but also is conducive to the effective promotion of the reform experiences.

\section{Results}

The study found that the content and effect of innovation and entrepreneurship education reform of business 
administration major of University of Science and Technology Liaoning are as follows:

\subsection{Reform Content}

\subsubsection{Training Program Reform}

(1) Updating training program

Compared with the traditional training program, students' sense, ability and interest of innovation and entrepreneurship are evaluated by the theoretical test, simulation reply and more other ways in the updated training program, which is helpful for teachers to screen out the students of entrepreneurship practice class in a more scientific way. In addition, the training process is divided into three stages as shown in Figure 1.

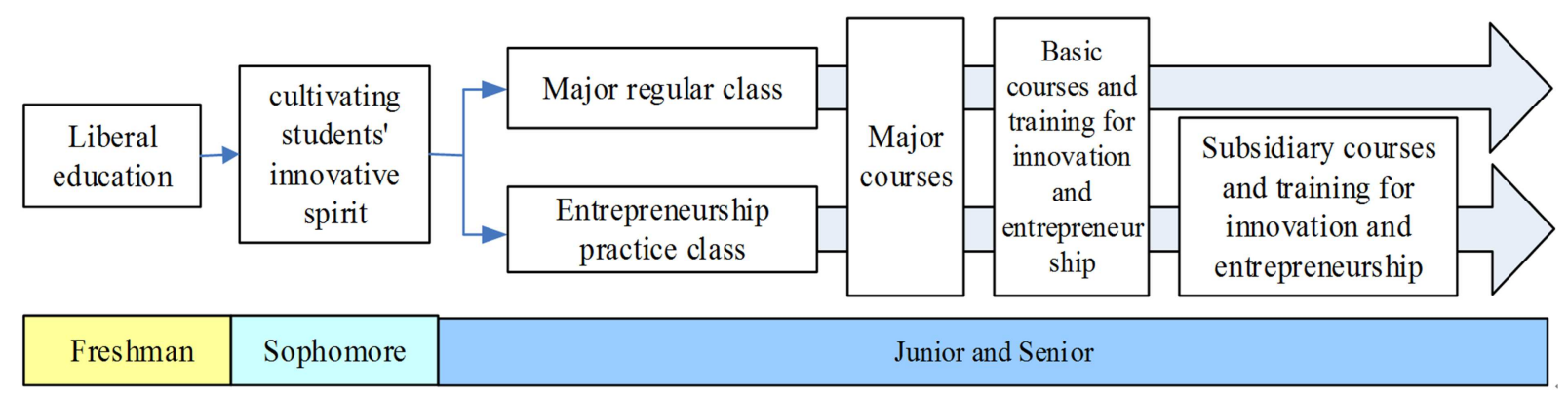

Figure 1. Three Stages of Training Process.

(2) The new training concept

In terms of time, the innovation and entrepreneurship courses are set up every year. In teaching, more teaching methods such as heuristic and discussion are adopted to encourage students to question and criticize daringly, cultivating students' creative thinking and entrepreneurship consciousness. In examination, more innovative test proposition are selected to encourage students to think independently, cultivate students' skepticism and adventure, and inspire them to solve new problems with the innovative thinking; In practice, graduation thesis and social practice and other aspects, the content of innovation and entrepreneurship also are increased to cultivate students' ability of innovation and entrepreneurship.

(3) The new teaching mode

The new teaching mode is established from multi angles to create the growth environment of future entrepreneurs. First, outside entrepreneurs, school teachers and entrepreneurial teams are invited to discuss business case collectively, developing the ability to analyze and solve problems for students. Secondly, quality development training is carried out regularly to temper the entrepreneurial team's indomitable character. Thirdly, outside school entrepreneurs and school teachers are recommended to jointly guide the entrepreneurship projects, solving the problems in the actual operation process. Fourthly, this major also applies to the school and college for office space, office equipment, and even stores, to help students reduce entrepreneurship cost. Fifthly, the major assists entrepreneur teams to raise start-up fund, to ensure the smooth development of the team business. Sixthly, relevant government personnel are employed to interpret national and local preferential policies, to provide more support for the entrepreneur teams. At last, the teams developing well will be recommended to the business incubators of school, city, and province, to provide a broader platform for them.

(4) The new practice system

The first classroom and the second classroom are carried on synchronously. Students are encouraged to participate ERP Association, Entrepreneurship Association, Investment Banking Association and other innovation and entrepreneurship activities; Teachers and students are encouraged to participate in the innovation and entrepreneurship training program projects. The major helps to hatch those projects with strong entrepreneurial willingness and high feasibility; The docking mechanism has been established between teachers and students entrepreneurial team; Besides, the solid cognitive practice, professional practice, graduation practice, social practice and other activities are carried out to enhance students' practical ability and awareness.

(5) Creating a "business + " collaborative entrepreneurial platform

University of Science and Technology Liaoning is a comprehensive university. Therefore, almost all the other disciplines students often need to seek the students from business administration major to join their entrepreneurial teams. Under such background, the business administration major has actively created a "business $+"$ collaborative entrepreneurial platform, which opens up the business channel between multiple majors, such as business administration major and mechanical engineering major, business administration major and chemical engineering major, business administration major and art major and so on.

(6) Setting up an entrepreneur club and carrying out project roadshows

The major encouraged the students from entrepreneurship practice class to establish an entrepreneur club, promoting students to share information and exchange entrepreneurial experience. Students conducts occasional project roadshows. They put their entrepreneurial projects in the spotlight, learning to examine every project in the height of the entrepreneurs. In addition, they may have the opportunity to get the incubation funds by introducing their entrepreneurial projects to partners and Venture Capital Company by this way. 


\subsubsection{Curriculum System Reform}

(1) The new Course Framework

The new course system will be composed of two major modules, namely professional basic course group and innovation and entrepreneurship course group. The sub module, new technology topic, is added to show the development direction of related industries for students. The type and proportion of innovation and entrepreneurship courses are different for entrepreneurship practice class and major regular class. The teaching resources and class types are matched as shown in table 2 . On the whole, no matter what kind of class, the innovation and entrepreneurship education has been carried on continuously for four years.

Table 2. Matching Ratio of Teaching Resources.

\begin{tabular}{llll}
\hline \multirow{2}{*}{ Class type } & \multicolumn{2}{l}{$\begin{array}{l}\text { Proportion of innovation and entrepreneurship courses } \\
\text { Innovation courses }\end{array}$} & $\begin{array}{l}\text { Proportion of Business } \\
\text { Administration Courses }\end{array}$ \\
\hline Entrepreneurship practice class & $10 \%$ & $15 \%$ & $75 \%$ \\
Major regular class & $5 \%$ & $10 \%$ & $85 \%$ \\
\hline
\end{tabular}

(2) The new course system

Drawing lessons from domestic and foreign experience, on the basic courses of Creative Thinking and Creative Method, Entrepreneurial Management, Career Planning and other courses, some required courses including Entrepreneurship and Innovation, Introduction to New Industries and Enterprise Ethics and some elective courses such as Business Model Innovation, Management Innovation, Case Study of Entrepreneurial Combat, Corporate Finance, Business Plan and so on are also added to the new course system to highlight the specialty characteristic

(3) Implementation of credits alternative plan

The credits alternative plan is implemented in entrepreneurship practice class. The plan allows students to use certain entrepreneurship elective courses to replace professional elective courses or required courses. It further stimulates students' interest in innovation and entrepreneurship, and strengthens their ability of innovation and entrepreneurship. The implementation plan is shown in Figure 2.

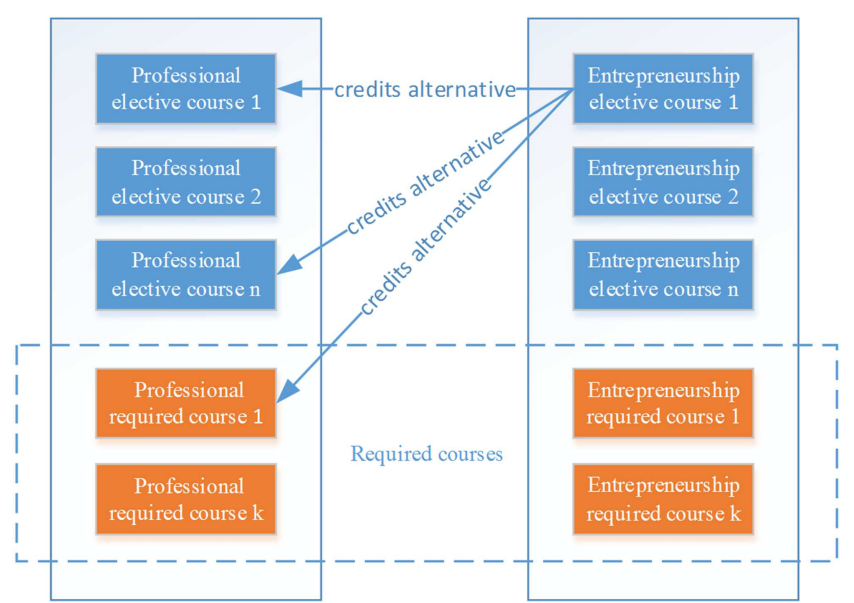

Figure 2. The Credits Alternative Plan for Entrepreneurship Practice Class.

\subsubsection{Teaching Resources Reform}

(1) Making full use of the U type classrooms

Students' thinking, speaking and team awareness are strengthened by giving full play the teaching interaction effect of $U$ type classroom. The students are trained according to the training requirements of SIYB (Produce your business, start your business, improve your business, and expand your business).

(2) Developing new teaching resources

Combined with professional features, the major has published a series of teaching materials which integrating professional education with innovation and entrepreneurship education, Taking 2-3 core courses as the object, a set of three-dimensional teaching material is constructed in this major, which covers the main body of knowledge, case analysis, examination questions database, lesson plans, courseware and other content. Referring to the thinking of Massive open online course (MOOCs) and modern information technology, the major has realized the convenience of teaching and learning.

(3) Deepening the construction of the platform base

To improve the quality and level of practice teaching, the major deepens the construction of the platform base by expanding the quantity and improving the quality. It develops high-level, representative enterprises as new practice bases to help students grasp the new trends and areas of science and technology development and establish innovation spirit and innovation awareness.

(4) Building a cooperative and diversified teaching resources system

Drawing lessons from the construction achievement of domestic and foreign universities, such as Stanford University, Massachusetts Institute of Technology, Tsinghua University, Tsinghua University, Renmin University of China, Beihang University, Shanghai Jiao Tong University, etc., the major is trying to establish a cooperative relationship with them so as to learn their excellent training modes, share teaching resources, and build a cooperative and diversified teaching resources system at last.

(5) Mining and sharing social resources

The major cooperate with enterprises, research institute, government departments and so on to mine and share cross-industry, cross-domain, cross-sector, and cross-regional social resources. An innovation and entrepreneurship service network has been built for students to provide more innovation and entrepreneurship training and incubation support.

\subsubsection{Teaching Staff Reform}

(1) Strengthening the system construction of teaching staff Cultivating the teacher engaged in innovation and 
entrepreneurship education has been put into the overall development planning of teaching staff. The corresponding teacher training program, teacher evaluation index system, innovation and entrepreneurship education incentive mechanism and other supporting systems have also been formulated to encourage teachers to merge the innovation and entrepreneurship education in teaching and scientific research

(2) Deepening exchanges and cooperation mechanism

The overall education level of teachers is improved by deepening exchanges and cooperation mechanism. To broaden teachers' horizons and improve their teaching level, some teachers are sent to some universities to learn and exchange experience. On the other hand, to further strengthening the cooperation between the universities at home and abroad, excellent teachers have been hired each other mutually by these universities. Sharing excellent teacher resources helps the major to enhance the overall education level of teachers.

(3) Setting up an omnibus teaching staff

The outstanding part-time teachers from the industry are employed. The related employment mechanism, employment conditions and procedures, pay treatment, teaching tasks, and evaluation mechanism also have been regulated. The scholars, government officials, entrepreneurs, persons who are successful or even frustrated in business from all sectors of society are employed as the part-time teachers to achieve effective integration of school and social resources.

(4) Cultivating a number of expert teachers

Some teachers are arranged to go deep into the enterprises every year to be familiar with the operation and management of enterprises. The related policies and financial supports are also provided for teachers' self-learning and training, which is helpful to cultivate a group of expert teachers who are good at innovation and entrepreneurship.

\subsection{Reform Effect}

The reform has made the business administration major of University of Science and Technology Liaoning achieve a series of good results as follows. First, innovation and entrepreneurship education and professional education are integrated deeply with full coverage, whole process, and total factors in this major; Second, the training program is more systematic and the curriculum system is more reasonable, which achieved close combination of the innovation and entrepreneurship education with the first classroom and the second classroom; Third, teaching resources become increasingly rich, the teachers' education level has been improved steadily, and teaching methods and means are more applicable; Forth, students' innovation and entrepreneurship awareness and ability are enhanced significantly, and a number of innovation and entrepreneurship teams are emerging.

\section{Conclusion and Recommendations}

\subsection{Conclusion}

The innovation and entrepreneurship education reform of the business administration major of University of Science and Technology Liaoning includes four aspects: training program, curriculum system, teaching resources and teaching staff, which cover 23 initiatives. It has achieved an obvious demonstration role in many related majors. Although the results of this study cannot fit for all the business administration majors of all kinds of colleges and universities, because the development environment and specialty characteristics of different business administration major are not the same, it can partly reflect the focuses and trends of innovation and entrepreneurship education reform of business administration majors. Therefore, the related majors from the colleges and universities can get many useful references.

\subsection{Recommendations}

It is a systematic project to realize the integration of professional education and innovation and entrepreneurship education. Therefore, combined with this case study, the following suggestions are put forward. First, the reform requires collaborative supports of multi-level management departments of universities, which requires to optimize and innovate some traditional management systems and processes. Second, the enthusiasm and motivation of the front line teachers for the reform is very important, so it is necessary to establish the corresponding incentive mechanism and safeguard measures. Third, it is very important to compact and construct the specialty characteristics. The characteristic of business administration major of University of Science and Technology Liaoning is to set up the basic goal of integrating professional education and innovation and entrepreneurship education, and also to create the characteristic goal of cultivating students to set up the spirit of entrepreneurship. The related universities cannot completely copy this characteristics of the major. Forth, the key to classification training is to screen students. Both missing the students with entrepreneurial potential and accepting the students with weak entrepreneurial ability will be the regrets of innovation and entrepreneurship education reform. A scientific, rigorous and efficient evaluation mechanism is essential to cultivate and classify the students. The innovation spirit, entrepreneurial awareness and entrepreneurial ability are essential conditions to become a student of entrepreneurship practice class.

\section{Acknowledgements}

This work is supported by the undergraduate teaching reform research project of higher education of Liaoning province in 2014 under Grant No. UPRP20140203, the innovation and entrepreneurship education reform pilot major project of University of Science and Technology Liaoning in 2015, and the innovation and entrepreneurship teaching reform project of University of Science and Technology Liaoning in 2015 under Grant NO. cxcy-2015-21 and NO. cxcy-2015-36. 


\section{References}

[1] Z. Yang, B. A. School, and W. B. University, "Problems and Countermeasures in Innovation and Entrepreneurship Education of Application-oriented College," Logistics Engineering \& Management, vol. 36, pp. 230-232, 2014.

[2] B. Zhang, G. U. Zaiqiu, and C. University, "Practices of Integration Entrepreneurship Education in Professional Education of Business Administration-Taking Logistics Management Major a Case," Journal of Changchun University, vol. 24, pp. 1080-1082, 2014.

[3] X. M. Tang, "Research on Innovation Training Way of Business Administration Major," World \& Chongqing, pp. 9-12, 2015.

[4] X. Liu, and Q. Wang, "Discussion on New Measures for Universities to Promote and Deepen Innovation and Entrepreneurship Education Reform," Advances in Computer Science Research, vol. 37, pp. 1611-1613, 2016.

[5] Z. Li, "Study on the Personnel Cultivation Model of Administration Major of Vocational College Based on College-Enterprise Integration," Journal of Qilu Normal University, vol. 29, pp. 81-87, 2014.

[6] G. H. Jiang, "Research on the Personnel Cultivation Model of Administration Major in Local Universities," Journal of Nantong University, vol. 24, pp. 51-55, 2008.

[7] C. S. Marques, M. Trevisan, and A. C. d. Cruz, "Treading paths to sustainability: an analysis of the postgraduate curriculum in Business Administration," Brazilian Journal of Science and Technology, vol. 3, pp. 1-16, 2016.

[8] M. Zhou, and H. Xu, "A Review of Entrepreneurship Education for College Students in China," Administrative Sciences, vol. 2 , pp. 82-98, 2012.

[9] J. Liu, "An Analysis of the Implementation Mechanism of Innovation and Entrepreneurship Education in China," Journal of Shangqiu Teachers College, vol. 27, pp. 95-98, 2011.

[10] S. Yi, "Study on the curriculum system of Business Administration (innovation and Entrepreneurship) in Open University," Shandong Industrial Technology, pp. 238-239, 2015.

[11] A. Fayolle, and B. Gailly, "The Impact of Entrepreneurship Education on Entrepreneurial Attitudes and Intention: Hysteresis and Persistence," Journal of Small Business Management, vol. 53, pp. 75-93, 2015.

[12] E. G. Carayannis, E. T. Samara, and Y. L. Bakouros, Entrepreneurship and Innovation Practices: Springer International Publishing, 2015.

[13] L. J. Shen, "An Analysis of the Strategies on College-Wide Entrepreneurship Education in American Community Colleges," Comparative Education Review, 2014.

[14] G. L. Wang, and Z. Q. Yang, "Development Experience of
Entrepreneurship Education in the Colleges and Universities of the United States and Japan and Its Enlightenment," Journal of Chongqing Technology \& Business University, 2014.

[15] S. P. Liang, "A Study and Enlightenment of American Entrepreneurship Education_-Taking Stanford University and Babson College as the examples," Researches in Medical Education, 2006.

[16] T. Hu, and L. Shen, "The Enlightenment of foreign innovation and entrepreneurship education model for China's colleges and Universities," China University Teaching, pp. 91-94+90, 2013.

[17] Z. Wu, "Education of creation and innovation in colleges and its revelation," Journal of Nanchang Institute of Technology, vol. 26 , pp. $18-22,2007$.

[18] Z. Shen, "Thinking on cultivating innovative talents in teaching oriented universities," Education and Vocation, pp. 44-46, 2010 .

[19] Y. Wang, "Reflection and pattern construction of innovation and entrepreneurship education in Colleges and Universities," China University Teaching, pp. 4-7+24, 2015.

[20] W. Guo, H. Sun, and S. Han, "Analysis and Countermeasures of innovation and entrepreneurship education in Colleges and Universities," Heilongjiang Education (Higher Education Research \& Appraisal), pp. 52-53, 2014.

[21] Q. Zhu, and X. Wu, "Thoughts on patent related education in economic management major," Northern Economy and Trade, pp. 121-122, 2014.

[22] W. Chen, "Analysis on the development of innovation and entrepreneurship education in Business Administration," Contemporary Education Research and Teaching Practice, pp. 144-145, 2015.

[23] K. Deng, "Practice research on the innovation and entrepreneurship education mode of College Students -- Taking Beijing City University as an example," China Education Innovation Herald, pp. 15-15, 2014.

[24] Q. Li, M. Li, and B. Yin, "Research on the innovation and entrepreneurship education system of business administration in Universities -- Taking Changzhou University as an example," Human Resource Management, pp. 166-167, 2013.

[25] J. Gerring, "What Is a Case Study and What Is It Good for?," American Political Science Review, vol. 98, pp. 341-354, 2004.

[26] S. B. Merriam, "Case Study Research in Education: A Qualitative Approach," Case Studies, vol. 18, pp. 246, 1988.

[27] M. Ketcherside, E. Puett, C. Banez, and M. K. Maher, "Interprofessional Clinical Education Case Study Competition from the Public Health Perspective," Clinica Chimica Acta, vol. 35, pp. 473-481, 2015.

[28] M. Gasman, J. Kim, and T. H. Nguyen, "Effectively Recruiting Faculty of Color at Highly Selective Institutions: A School of Education Case Study," Journal of Diversity in Higher Education, vol. 4, pp. 212-222, 2011. 